\title{
Pemanfaatan Media Sosial untuk Mendukung Kegiatan Penyuluhan Pertanian di Kabupaten Minahasa Provinsi Sulawesi Utara
}

\section{Utilization of Social Media to Support Agricultural Extension Activities in Minahasa Regency, North Sulawesi Province}

\author{
Suratini $^{1)}$, Pudji Muljono, Cahyono Tri Wibowo ${ }^{2)}$ \\ ${ }^{1}$ Pascasarjana Program Studi Komunikasi Pembangunan Pertanian dan Pedesaan, Institut Pertanian Bogor, Bogor 16680, Indonesia \\ ${ }^{2}$ Program Studi Komunikasi Pembangunan Pertanian dan Pedesaan, Sps-IPB, Bogor 16680, Indonesia \\ ${ }^{*}$ E-mail: rati.ungu@gmail.com
}

Diterima: 16 Juli 2020 | Disetujui: 16 Februari 2021 | Publikasi Online: 17 Februari 2021

\begin{abstract}
The rapid development of communication technology requires agricultural extension workers to be able to use social media in disseminating agricultural information. This study aims to describe the use of social media, analyze the factors associated with the level of social media utilization and analyze the management of agricultural information and its relationship with the use of social media. The study used the observation method to select respondents through the census.The level of social media utilization by respondents was measured by the frequency and duration in using Facebook, WhatsApp, Youtube and Instagram. The frequency of using social media is relatively high for Facebook and WhatsApp. The overall duration of accessing social media is relatively low. Factors that are significantly related to the utilization level of social media are the characteristics of extension workers (level of education and the availability of communication technology tools), perception of extension workers (ease of acces to information), information needs of extension workers (climate and capital) and motivation of extension workers (increasing knowledge and insight). Almost all extension workers manage information obtained from social media to be distributed to farmers.
\end{abstract}

Keywords: agricultural extension workers, agricultural information, social media

\section{ABSTRAK}

Pesatnya perkembangan teknologi komunikasi menuntut penyuluh agar mampu memanfaatkan media sosial dalam mendiseminasikan informasi pertanian. Penelitian ini bertujuan untuk mendeskripsikan pemanfaatan media sosial, menganalisis faktor-faktor yang berhubungan dengan tingkat pemanfaatan media sosial dan menganalisis pengelolaan informasi pertanian serta hubungannya dengan pemanfaatan media sosial. Penelitian dilakukan menggunakan metode observasi dengan pemilihan responden melalui sensus. Tingkat pemanfaatan media sosial oleh responden diukur dari frekuensi dan durasi pemanfaatan media sosial Facebook, WhatsApp, Youtube dan Instagram. Frekuensi pemanfaatan media sosial tergolong tinggi pada Facebook dan WhatsApp. Durasi pemanfaatan keseluruhan media sosial tergolong rendah. Faktor yang berhubungan nyata dengan tingkat pemanfaatan media sosial adalah karakteristik penyuluh (tingkat pendidikan dan ketersediaan alat teknologi komunikasi), persepsi penyuluh (kemudahan mengakses informasi), kebutuhan informasi penyuluh (iklim dan permodalan) dan motivasi penyuluh (meningkatkan pengetahuan dan wawasan). Mayoritas penyuluh mengelola informasi yang diperoleh dari media sosial untuk disebarkan kepada petani.

Kata kunci: penyuluh pertanian, informasi pertanian, media sosial

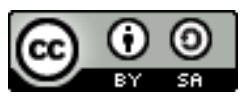




\section{PENDAHULUAN}

Perkembangan ilmu pengetahuan dan teknologi dewasa ini menghasilkan banyak media komunikasi yang dapat digunakan untuk berbagi informasi secara cepat. Banyaknya alternatif media komunikasi yang tersedia membutuhkan pertimbangan dan perencanaan dalam pemilihan/penetapan dan penggunaan media komunikasi yang tepat untuk membantu mendiseminasikan informasi. Penggunaan media komunikasi yang tepat akan memudahkan informasi tersebut mencapai sasaran (user) secara efektif dan efisien. Menurut laporan terbaru Hootsuite bulan Juli 2019, lebih dari 3,5 miliar manusia di bumi bergabung ke media sosial. Total penduduk dunia mencapai 7,697 miliar, sebanyak $46 \%$ atau hampir setengah dari total populasi manusia di dunia merupakan pengguna aktif media sosial. Pertumbuhan pengguna media sosial secara global dalam setahun mencapai lebih dari seperempat miliar (Pertiwi 2019, Riyanto 2019). Hasil riset Hootsuit tersebut juga menjelaskan bahwa pengguna media sosial di Indonesia mencapai 150 juta atau sekitar 56\% dari total populasi.

Kemajuan teknologi komunikasi dan informasi semakin memudahkan khalayak untuk berinteraksi. Seperti halnya internet yang saat ini menjadi bagian aktivitas masyarakat di berbagai kalangan. Fenomena media sosial online di internet seperti google, yahoo, facebook, twitter, dan lain-lain saat ini sedang ramai diperbincangkan. Hal tersebut tidak terlepas dari manfaat yang diberikan oleh media sosial tersebut. Manfaat yang diberikan berupa kemudahan mengakses informasi dan isu-isu yang sedang berkembang. Salah satu bidang yang memperoleh manfaat dengan kemajuan teknologi informasi adalah bidang pertanian. Melalui media sosial, informasi terkait pertanian moderen akan mudah diperoleh. Hal tersebut memberikan kesempatan kepada penyuluh dan petani untuk memperoleh informasi teknis dan ekonomis dengan cepat dan menggunakannya secara efektif dan efisien untuk pengambilan keputusan (Destrian et al., 2018).

Pendekatan teori uses and gratifications telah banyak digunakan untuk meneliti penggunaan media oleh khalayak. Menurut Ruggiero (2000), pendekatan Uses and Gratifications digunakan dalam penggunaan media massa baru seperti surat kabar, radio, televisi dan kini internet. Dalam lingkungan internet, pengguna dipandang lebih aktif berpartisipasi dalam menggunakan media baru dibandingkan dengan media tradisional. Hal tersebut sejalan dengan pendekatan Uses and Gratifications yang memandang bahwa pemilihan media dapat memberikan kepuasan kepada khalayak dalam memenuhi kebutuhannya dan khalayak dapat memahami berbagai alasan dalam menggunakan media. Para peneliti menggunakan pendekatan Uses and Gratifications untuk menjelaskan pemilihan serta penggunaan media baru seperti internet dan aplikasinya yang dilakukan oleh khalayak. Pendekatan Uses and Gratifications telah digunakan untuk meneliti penggunaan media baru antara lain penggunaan telepon genggam, penggunaan internet, penggunaan media sosial, penggunaan situs jejaring sosial, penggunaan microblogging, penggunaan pesan instan, penggunaan permainan daring, penggunaan berita beranimasi, serta penggunaan media hiburan. Sejalan dengan hal tersebut, Amin et al. (2013) menyatakan bahwa fokus utama dari aplikasi ICT (Information and Communication Technology) di bidang pertanian adalah memenuhi kebutuhan petani untuk informasi. Pemanfaatan ICT dalam pembangunan pertanian memerlukan kompetensi dari pengguna teknologi informasi dan komunikasi. Dalam hal ini petani hanya dapat mengandalkan kapasitas penyuluh dalam mendampingi petani mengembangkan proses belajar inovasi pertanian, sehingga kemajuan ICT memungkinkan potensi menjadi peluang yang besar bagi para pelaku pembangunan pertanian termasuk penyuluh untuk mengakses informasi yang dibutuhkan.

Keberhasilan pelaksanaan program penyuluhan dipengaruhi oleh banyak faktor yang dapat dikelompokkan ke dalam faktor yang berkaitan dengan karakteristik penyuluh (Viforit et al., 2014), kompetensi, motivasi, kemandirian penyuluh (Bahua et al., 2010), organisasi dan dukungan inovasi (Marius et al. 2007; Suhanda et al. 2008; Suharjon et al. 2017) dan latar belakang sosial budaya masyarakat petani (Amanah 2008; Marliati et al. 2008). Dalam melaksanakan tugas di lapangan, penyuluh pertanian membutuhkan informasi hasil penelitian yang relevan dengan permasalahan yang ada di lapangan. Menurut Syam dan Widjono dalam Kushartanti (2001), informasi/teknologi pertanian dan hasil penelitian yang akan dijadikan materi penyuluhan pertanian hendaknya yang relevan dengan permasalahan yang dihadapi oleh petani. Menurut Mulyandari (2011), Dasli et al. (2015) dan Elian et al. (2014), ada beberapa faktor yang melatarbelakangi penyuluh dan petani jika ingin memanfaatkan 
teknologi informasi, termasuk didalamnya media sosial. Mulai dari umur, pendidikan formal, pendapatan, kepemilikan sarana teknologi informasi, lama menggunakannya, luas lahan, tingkat kosmopolitan, persepsi terhadap teknologi informasi, motivasi, perilaku dalam pemanfaatan teknologi informasi, jenis pelatihan yang pernah diikuti, dan keterlibatan dalam kelompok.

Di negara berkembang seperti di Indonesia, kurangnya frekuensi layanan penyuluhan berpengaruh terhadap penyebaran teknologi baru dan dalam penyelesaian masalah yang dihadapi petani. Penyuluhan dilihat sebagai jembatan antara peneliti dan petani, sebuah jembatan untuk menghubungkan prosesi satu arah tentang perkembangan teknologi terbaru, kebijakan pertanian dan bagaimana teknologi tersebut bisa dimanfaatkan oleh petani (Margono \& Sugimoto, 2011). Sejalan dengan hal tersebut menurut Matthew et al. (2017), sistem penyuluhan pertanian yang efektif perlu menyediakan berbagai tindakan yang dibutuhkan oleh petani sehingga petani dapat mengelola pertanian dengan lebih baik. Berdasarkan hasil penelitian Anwas (2009), salah satu penyebab ketidakhandalan penyuluh di lapangan adalah lemahnya sistem informasi pertanian, yang dibuktikan dari rendahnya pemanfaatan media massa (koran, buku, radio, komputer dan internet). Selanjutnya dijelaskan bahwa rendahnya pemanfaatan media tersebut disebabkan oleh keterbatasan kepemilikan media informasi dan komunikasi, rendahnya kualitas sumber informasi, dan terbatasnya kemampuan sumber informasi dalam menyediakan informasi pertanian yang relevan dan tepat waktu bagi petani. Menurut Wicaksono et al. (2016), terdapat pengaruh yang signifikan secara langsung antara kompetensi penyuluh pertanian dengan kinerjanya terutama kaitannya dengan bagaimana penyuluh memanfaatkan teknologi informasi dan komunikasi dalam mendiseminasikan informasi pertanian kepada petani.

Penelitian terkait pemanfaatan media dalam mendukung kegiatan penyuluhan telah dilakukan oleh beberapa peneliti terdahulu antara lain; pemanfaatan informasi teknologi pertanian oleh penyuluh pertanian (Suryantini 2001), hambatan penyuluh dalam mendiseminasikan informasi pertanian (Margono et al. 2011), pemanfaatan media komunikasi cyber extension (Mulyandari 2011), penggunaan internet untuk memperoleh informasi pertanian oleh penyuluh pertanian (Elian et al. 2014), pemanfaatan internet oleh penyuluh pertanian (Eksanika dan Riyanto 2017), pemanfaatan media sosial facebook dalam penyuluhan pertanian dan perikanan (Prayoga 2017), pemanfaatan internet dalam meningkatkan kinerja penyuluh pertanian (Purwatiningsih et al. 2018), kinerja penyuluh pertanian dalam pemanfaatan cyber extension (Sabir et al. 2018). Hasil-hasil penelitian tersebut umumnya mengungkapkan keterkaitan pemanfaatan media secara umum dalam kegiatan penyuluhan, namun penelitian spesifik terkait pemanfaatan media sosial Facebook, Youtube, WhatsApp dan Instagram dalam mendukung kegiatan penyuluhan belum pernah dilakukan. Untuk itu penelitian pemanfaatan media sosial Facebook, Youtube, WhatsApp dan Instagram untuk mendukung kegiatan penyuluhan pertanian di kabupaten Minahasa Provinsi Sulawesi Utara perlu dilakukan.

Penelitian ini bertujuan untuk: (1) Mendeskripsikan pemanfaatan media sosial oleh penyuluh pertanian, (2) Menganalisis faktor-faktor yang berhubungan dengan tingkat pemanfaatan media sosial oleh penyuluh pertanian, (3) Menganalisis pengelolaan informasi pertanian yang diperoleh penyuluh dari media sosial.

\section{METODE PENELITIAN}

Penelitian ini menggunakan metode observasi yang bersifat deskriptif korelasional. Pengumpulan data dilakukan selama bulan Februari sampai Maret 2020. Penentuan lokasi dilakukan secara purpossive sampling dengan pertimbangan Kabupaten Minahasa merupakan salah satu Kabupaten yang mempunyai akses internet cukup baik dan merata di Sulawesi Utara, serta jumlah penyuluh di wilayah ini relatif banyak. Responden penelitian adalah penyuluh pertanian yang bertugas di Kabupaten Minahasa Provinsi Sulawesi Utara, diambil secara sensus sebanyak 125 orang. Data dikumpulkan melalui observasi langsung, mengajukan kuesioner dan teknik wawancara. Parameter yang diamati meliputi karakteristik penyuluh, persepsi penyuluh, kebutuhan informasi dan motivasi penyuluh terhadap empat media sosial yaitu: Facebook, Youtube, WhatsApp dan Instagram. Analisis data 
menggunakan analisis statistik deskriptif dan analisis uji korelasi Rank Spearman dengan aplikasi SPSS versi 19.

\section{HASIL DAN PEMBAHASAN}

\section{Pemanfaatan Media Sosial oleh Penyuluh Pertanian}

Pemanfaatan media sosial oleh penyuluh pertanian adalah intensitas mengakses media sosial yang menggambarkan frekuensi dan durasi penyuluh pertanian memanfaatkan media sosial untuk mendapatkan informasi pertanian. Tingkat pemanfaatan media sosial oleh penyuluh ditampilkan pada Tabel 1.

Tabel 1. Persentase penyuluh berdasarkan tingkat pemanfaatan media sosial

\begin{tabular}{|c|c|c|c|c|c|c|c|c|}
\hline \multirow{2}{*}{$\begin{array}{c}\text { Tingkat } \\
\text { Pemanfaatan Media } \\
\text { Sosial }\end{array}$} & \multicolumn{8}{|c|}{ Pengguna Media Sosial } \\
\hline & FB (orang) & $\%$ & $\begin{array}{l}\text { Youtube } \\
\text { (orang) }\end{array}$ & $\%$ & WA (orang) & $\%$ & $\begin{array}{c}\text { IG } \\
\text { (orang) }\end{array}$ & $\%$ \\
\hline \multicolumn{9}{|l|}{1 Frekuensi } \\
\hline$<3 \mathrm{kali} / \mathrm{minggu}$ & 32 & 26,7 & 37 & 33,1 & 30 & 25,0 & 22 & 73,4 \\
\hline 3-5 kali/minggu & 39 & 32,5 & 51 & 45,5 & 36 & 30,0 & 5 & 16,6 \\
\hline$>5 \mathrm{kali} / \mathrm{minggu}$ & 49 & 40,8 & 24 & 21,4 & 54 & 45,0 & 3 & 10,0 \\
\hline \multicolumn{9}{|l|}{2 Durasi } \\
\hline$<3 \mathrm{jam} / \mathrm{hari}$ & 114 & 95,0 & 104 & 92,8 & 111 & 92,5 & 28 & 93,3 \\
\hline 3-6 jam/hari & 5 & 4,2 & 8 & 7,2 & 9 & 7,5 & 2 & 6,7 \\
\hline$>6$ jam/hari & 1 & 0,8 & 0 & 0,0 & 0 & 0,0 & 0 & 0,0 \\
\hline
\end{tabular}

Tabel 1 menunjukkan persentase penyuluh menggunakan media sosial berdasarkan frekuensi penggunaan dalam satu minggu tergolong tinggi pada penggunaan media sosial WhatsApp dan Facebook. Namun, secara durasi pemanfaatan keempat media sosial masih tergolong rendah. Penyuluh memanfaatkan media sosial masih kurang dari tiga jam dalam sehari. Sebagian besar penyuluh memanfaatkan media sosial dalam waktu yang relatif singkat. Hal tersebut mengingat penyuluh mempunyai kegiatan utama melakukan kunjungan ke petani maupun kelompok tani yang dilakukan hampir setiap hari sehingga tidak mempunyai waktu yang cukup untuk mengakses informasi pertanian dari media sosial. Penelitian Supratman (2018) menyatakan bahwa seseorang menggunakan media sosial untuk mendapatkan informasi, berkomunikasi secara virtual, mengeksplorasi hobi, memperoleh hiburan, menunjang tugas, melakukan pembelajaran daring serta pengadopsian gaya hidup. Hal tersebut terkait dengan motif penyuluh dalam memanfaatan media sosial sehingga berpengaruh pada frekuensi maupun durasi dalam mengakses media sosial. Ragam informasi yang sering diakses oleh penyuluh dalam rangka memperoleh informasi pertanian dijelaskan pada Tabel 2 di bawah ini.

Tabel 2. Persentase penyuluh berdasarkan ragam informasi yang paling sering diakses

\begin{tabular}{lcc}
\hline \multirow{2}{*}{ Informasi yang sering diakses } & Jumlah responden & \\
\cline { 2 - 3 } & (orang) & $\mathbf{( \% )}$ \\
\hline Kebijakan pertanian & 14 & 11.20 \\
Teknis produksi pertanian/peternakan & 71 & 56.80 \\
Pemasaran dan permodalan & 16 & 12.80 \\
Penggunaan alsintan pertanian & 8 & 6.40 \\
Konstratani & 4 & 3.20 \\
Pelatihan penyuluhan & 12 & 9.60 \\
\hline
\end{tabular}

Berdasarkan Tabel 2 terlihat bahwa ragam informasi pertanian yang paling sering diakses penyuluh adalah tentang teknis produksi pertanian/peternakan $(56,80 \%)$. Hal ini sesuai dengan kebutuhan petani di lapangan yang lebih banyak membutuhkan informasi tentang teknis produksi pertanian/peternakan dibandingkan dengan informasi lainnya. Hal tersebut sejalan dengan penelitian Humaidi et al. (2020) yang menyatakan bahwa media sosial sebagai media online yang dapat dimanfaatkan penyuluh secara mudah dalam mengakses informasi, menciptakan pesan, berinteraksi dan berpartisipasi yang dilakukan dengan berjejaring sosial secara cepat dan tidak terbatas termasuk konten pertanian. 
Analisis Faktor-faktor yang Berhubungan dengan Tingkat Pemanfaatan Media Sosial oleh Penyuluh Pertanian

\section{Karakteristik Penyuluh}

Karakteristik penyuluh merupakan aspek yang mempengaruhi penyuluh pertanian dalam menjalankan tugas dan fungsinya menyampaikan informasi pertanian kepada petani. Tabel 3 akan menjelaskan karakteristik penyuluh.

Tabel 3. Karakteristik penyuluh pertanian di Kabupaten Minahasa Provinsi Sulawesi Utara

\begin{tabular}{llcc}
\hline \multicolumn{1}{c}{ Karakteristik } & \multicolumn{1}{c}{ Kategorisasi } & Jumlah (orang) & Persentase (\%) \\
\hline Umur & Dewasa awal (26-35 tahun) & 5 & 4.00 \\
& Dewasa akhir (36-45 tahun) & 25 & 20.00 \\
& Lansia awal (46-55 tahun) & 75 & 60.00 \\
& Lansia akhir (56-65 tahun) & 20 & 16.00 \\
Pendidikan & SMA & 26 & 20.80 \\
& Diploma & 13 & 10.40 \\
& Sarjana & 84 & 67.20 \\
Penghasilan & Pascasarjana & 2 & 1.60 \\
& < Rp 4.600.000 & 77 & 61,60 \\
Kepemilikan Media & Rp 4.600.000 - Rp 8.300.000 & 46 & 36,80 \\
& $>$ Rp 8.300.000 & 2 & 1.60 \\
& < unit & 0 & 0.00 \\
& 2-3 unit & 120 & 96.00 \\
& $>3$ unit & & 4.00 \\
\hline
\end{tabular}

Berdasarkan Tabel 3 mayoritas penyuluh berada pada kisaran umur 46-55 tahun yang menunjukkan bahwa berada pada kisaran umur yang produktif untuk mengakses dan mendiseminasikan informasi pertanian kepada petani. Umumnya penyuluh berpendidikan sarjana $(67,20 \%)$ sehingga tingkat pendidikan yang tinggi tersebut sangat mendukung kinerjanya sebagai penyuluh pertanian. Hal tersebut sejalan dengan penelitian Nurfathiyah (2019) bahwa faktor yang mempengaruhi penyuluh pertanian dalam memanfaatkan media informasi diantaranya umur dan pendidikan. Dari segi penghasilan, sebagian besar penyuluh berpenghasilan kurang dari 4.600 .000 namun demikian dari kepemilikan media informasi, penyuluh rata-rata memiliki 2-3 media (handphone, laptop dan komputer). Fakta tersebut menunjukkan bahwa dengan umur yang produktif dan tingkat pendidikan yang tinggi, kesadaran penyuluh untuk memiliki media komunikasi cukup tinggi meskipun dengan penghasilan yang terbatas.

\section{Persepsi Penyuluh terhadap Media Sosial}

Persepsi penyuluh terhadap media sosial adalah pandangan atau penilaian penyuluh mengenai kemampuan media sosial dalam memenuhi kebutuhan informasi penyuluh dalam bidang pertanian. Penyuluh memiliki persepsi berbeda terhadap empat media sosial baik Facebook, Youtube, WhatsApp dan Instagram dalam memberikan kemudahan untuk akses informasi, kesesuaian informasi yang tersedia dengan kebutuhan penyuluh dan kualitas informasi dalam meningkatkan kapasitas penyuluh pertanian. Secara lebih rinci masing-masing persepsi penyuluh terhadap keempat media sosial tersebut dijabarkan pada Tabel 4, Tabel 5, Tabel 6 dan Tabel 7.

Fenomena di lapangan menunjukkan bahwa sebagian besar penyuluh menyatakan mudah untuk mengakses informasi pertanian dari Facebook. Dari total 125 penyuluh, yang mengakses Facebook sejumlah 120 orang. Selain itu, informasi pertanian yang diakses sesuai dengan kebutuhan penyuluh. Hal tersebut karena informasi yang ada pada Facebook biasanya selalu baru sehingga sering menjadi bahan materi untuk melakukan penyuluhan, namun demikian jika dilihat dari persentase jumlah penyuluh, secara kualitas informasi pertanian yang diperoleh dari Facebook belum dapat meningkatkan kapasitas penyuluh pertanian. Menurut Sasmito (2015) Facebook memiliki keunggulan mudah diakses baik melalui komputer, laptop, tablet maupun telepon genggam atau handphone. 
Tabel 4. Persentase penyuluh berdasarkan persepsi terhadap media sosial Facebook

\begin{tabular}{|c|c|c|c|c|c|c|c|c|}
\hline \multirow{3}{*}{$\begin{array}{l}\text { Persepsi terhadap media sosial } \\
\text { Facebook }\end{array}$} & \multicolumn{8}{|c|}{ Jumlah dan persentase responden } \\
\hline & \multicolumn{2}{|c|}{$\begin{array}{l}\text { Tidak } \\
\text { setuju }\end{array}$} & \multicolumn{2}{|c|}{$\begin{array}{l}\text { Cukup } \\
\text { Setuju }\end{array}$} & \multicolumn{2}{|c|}{ Setuju } & \multicolumn{2}{|c|}{ Sangat Setuju } \\
\hline & (org) & $(\%)$ & (org) & $(\%)$ & (org) & $(\%)$ & (org) & $(\%)$ \\
\hline $\begin{array}{l}\text { Penyuluh mudah untuk mengakses } \\
\text { informasi }\end{array}$ & 3 & 2.50 & 28 & 23.33 & 59 & 49.17 & 30 & 25.00 \\
\hline $\begin{array}{l}\text { Informasi yang diakses sesuai } \\
\text { dengan kebutuhan penyuluh }\end{array}$ & 5 & 4.16 & 45 & 37.50 & 58 & 48.34 & 12 & 10.00 \\
\hline $\begin{array}{l}\text { Kualitas informasi meningkatkan } \\
\text { kapasitas penyuluh }\end{array}$ & 6 & 5.00 & 60 & 50.00 & 46 & 38.33 & 8 & 6.67 \\
\hline
\end{tabular}

Tabel 5 menampilkan persepsi penyuluh terhadap media sosial Youtube. Pengguna Youtube sejumlah 112 orang dari total penyuluh. Youtube memberikan kemudahan untuk akses informasi, informasi yang diakses sesuai dengan kebutuhan penyuluh dan kualitas informasi dapat meningkatkan kapasitas penyuluh pertanian. Kondisi ini didukung oleh fitur Youtube yang variatif dan penyampaian yang mudah dipahami. Faiqah et al. (2016) menyatakan bahwa media sosial Youtube mempunyai data base video yang paling terkenal, paling lengkap dan variatif di dunia internet sehingga dapat memenuhi kebutuhan dari penggunanya.

Tabel 5. Persentase penyuluh berdasarkan persepsi terhadap media sosial Youtube

\begin{tabular}{|c|c|c|c|c|c|c|c|c|}
\hline \multirow{3}{*}{$\begin{array}{l}\text { Persepsi terhadap media } \\
\text { sosial Youtube }\end{array}$} & \multicolumn{8}{|c|}{ Jumlah dan persentase responden } \\
\hline & \multicolumn{2}{|c|}{$\begin{array}{l}\text { Tidak } \\
\text { setuju }\end{array}$} & \multicolumn{2}{|c|}{$\begin{array}{l}\text { Cukup } \\
\text { Setuju }\end{array}$} & \multicolumn{2}{|c|}{ Setuju } & \multicolumn{2}{|c|}{ Sangat Setuju } \\
\hline & (org) & $(\%)$ & (org) & $(\%)$ & (org) & $(\%)$ & (org) & $(\%)$ \\
\hline $\begin{array}{l}\text { Penyuluh mudah untuk } \\
\text { mengakses informasi }\end{array}$ & 3 & 2.67 & 37 & 33.03 & 56 & 50.00 & 16 & 14.28 \\
\hline $\begin{array}{l}\text { Informasi yang diakses sesuai } \\
\text { dengan kebutuhan penyuluh }\end{array}$ & 1 & 0.89 & 44 & 39.28 & 60 & 53.57 & 7 & 6.25 \\
\hline $\begin{array}{l}\text { Kualitas informasi } \\
\text { meningkatkan kapasitas } \\
\text { penyuluh }\end{array}$ & 1 & 0.89 & 51 & 45.53 & 54 & 48.21 & 6 & 5.35 \\
\hline
\end{tabular}

Tabel 6. Persentase penyuluh berdasarkan persepsi terhadap media sosial WhatsApp

\begin{tabular}{|c|c|c|c|c|c|c|c|c|}
\hline \multirow{3}{*}{$\begin{array}{c}\text { Persepsi terhadap media sosial } \\
\text { WhatsApp }\end{array}$} & \multicolumn{8}{|c|}{ Jumlah dan persentase responden } \\
\hline & \multicolumn{2}{|l|}{$\begin{array}{l}\text { Tidak } \\
\text { setuju }\end{array}$} & $\begin{array}{l}\text { Cukup } \\
\text { Setuju }\end{array}$ & \multicolumn{2}{|c|}{ Setuju } & \multicolumn{3}{|c|}{ Sangat Setuju } \\
\hline & (org) & $(\%)$ & (org) & $(\%)$ & (org) & $(\%)$ & (org) & $(\%)$ \\
\hline $\begin{array}{l}\text { Penyuluh mudah untuk } \\
\text { mengakses informasi }\end{array}$ & 6 & 5,00 & 38 & 31,67 & 60 & 50,00 & 16 & 13,33 \\
\hline $\begin{array}{l}\text { Informasi yang diakses sesuai } \\
\text { dengan kebutuhan penyuluh }\end{array}$ & 4 & 3,33 & 50 & 41,67 & 59 & 49,16 & 7 & 5,84 \\
\hline $\begin{array}{l}\text { Kualitas informasi } \\
\text { meningkatkan kapasitas } \\
\text { penyuluh }\end{array}$ & 6 & 5,00 & 58 & 48,34 & 52 & 43,33 & 4 & 3,33 \\
\hline
\end{tabular}

Pengguna WhatsApp ada 120 orang dari total penyuluh. Berdasarkan Tabel 6 penyuluh memiliki persepsi bahwa media sosial WhatsApp memberikan kemudahan untuk akses informasi. Selain itu informasi yang diakses dari WhatsApp juga sesuai dengan kebutuhan penyuluh terutama untuk memperoleh informasi baru bidang pertanian, namun demikian kualitas informasi pertanian yang diperoleh dari WhatsApp kurang dapat meningkatkan kapasitas penyuluh pertanian. Kondisi tersebut sesuai dengan fakta di lapangan bahwa hampir semua penyuluh tergabung dalam WhatsApp grup sehingga kebutuhan informasi pertanian bisa dibagikan dan didiskusikan. Hal tersebut sesuai dengan penelitian Rachmaniar and Anisa (2017) yang menyatakan bahwa alasan orang menggunakan 
WhatsApp adalah karena kebutuhan mendapatkan informasi terbaru, mempermudah komunikasi serta dapat merekatkan hubungan baik secara pribadi maupun kelompok.

Tabel 7. Persentase penyuluh berdasarkan persepsi terhadap media sosial Instagram

\begin{tabular}{|c|c|c|c|c|c|c|c|c|}
\hline \multirow{3}{*}{$\begin{array}{c}\text { Persepsi terhadap media sosial } \\
\text { Instagram }\end{array}$} & \multicolumn{8}{|c|}{ Jumlah dan persentase responden } \\
\hline & \multicolumn{2}{|l|}{$\begin{array}{l}\text { Tidak } \\
\text { setuju }\end{array}$} & $\begin{array}{l}\text { Cukup } \\
\text { Setuju } \\
\end{array}$ & \multicolumn{2}{|c|}{ Setuju } & \multicolumn{3}{|c|}{ Sangat Setuju } \\
\hline & (org) & $(\%)$ & (org) & $(\%)$ & (org) & $(\%)$ & (org) & $(\%)$ \\
\hline $\begin{array}{l}\text { Penyuluh mudah untuk mengakses } \\
\text { informasi }\end{array}$ & 4 & 13.33 & 17 & 56.67 & 7 & 23.33 & 2 & 6.67 \\
\hline $\begin{array}{l}\text { Informasi yang diakses sesuai } \\
\text { dengan kebutuhan penyuluh }\end{array}$ & 1 & 3.33 & 19 & 63.34 & 9 & 30.00 & 1 & 3.33 \\
\hline $\begin{array}{l}\text { Kualitas informasi meningkatkan } \\
\text { kapasitas penyuluh }\end{array}$ & 0 & 0.00 & 21 & 70.00 & 8 & 26.67 & 1 & 3.33 \\
\hline
\end{tabular}

Penyuluh pengguna media sosial Instagram relatif sedikit dalam penelitian ini. Pada Tabel 7 penyuluh memiliki persepsi bahwa media sosial Instagram cukup memberikan kemudahan untuk akses informasi, dan informasi yang diakses cukup sesuai dengan kebutuhan penyuluh, namun demikian secara kualitas informasi pertanian yang diperoleh dari Instagram masih kurang dapat meningkatkan kapasitas penyuluh pertanian. Hal tersebut diduga karena informasi yang tersedia pada Instagram hanya terbatas, tetapi karena penampilan informasinya yang simple dan informatif sehingga mudah dipahami oleh penyuluh. Seperti dikutip dari penelitian Helen and Rusdi (2018) yang menyatakan bahwa penggunan media sosial Instagram memiliki pengaruh terhadap kebutuhan informasi pengikutnya.

\section{Kebutuhan Informasi Penyuluh}

Kebutuhan informasi adalah tuntutan penyuluh pertanian untuk memperoleh informasi pertanian yang dibutuhkan untuk menunjang tugasnya. Berdasarkan hasil penelitian menunjukkan bahwa penyuluh mencari informasi yang dibutuhkan oleh petani ketika menghadapi permasalahan dalam usahataninya. Melalui penelusuran lewat media sosial, penyuluh akan mencari informasi yang dibutuhkan sehingga informasi tersebut bisa sekaligus menjadi bahan untuk materi penyuluhan pertanian pada pertemuan berikutnya dengan petani atau kelompok tani. Tabel 8 menampilkan beberapa jenis informasi yang dibutuhkan oleh penyuluh.

Tabel 8. Persentase penyuluh berdasarkan jenis informasi yang dibutuhkan

\begin{tabular}{lcccccc}
\hline \multirow{2}{*}{ Jenis informasi yang dibutuhkan } & \multicolumn{5}{c}{ Jumlah dan persentase penyuluh } \\
\cline { 2 - 7 } & \multicolumn{2}{c}{ Rendah } & \multicolumn{2}{c}{ Sedang } & \multicolumn{3}{c}{ Tinggi } \\
\cline { 2 - 7 } & (orang) & (\%) & (orang) & $(\boldsymbol{\%})$ & (orang) & $(\boldsymbol{\%})$ \\
\hline Teknologi produksi & 6 & 4.80 & 44 & 35.20 & 75 & 60.00 \\
Teknologi pengolahan hasil & 5 & 4.00 & 52 & 41.60 & 68 & 54.40 \\
Pemasaran & 4 & 3.20 & 53 & 42.40 & 68 & 54.40 \\
Iklim & 5 & 4.00 & 58 & 46.40 & 62 & 49.60 \\
Permodalan & 6 & 4.80 & 63 & 50.40 & 56 & 44.80 \\
\hline
\end{tabular}

Informasi teknologi produksi yang dibutuhkan oleh petani di wilayah penelitian meliputi benih/bibit unggul, cara penanaman, proses pemupukan, jadwal pengairan serta pengendalian organisme pengganggu tanaman (OPT). Petani juga membutuhkan informasi tentang teknologi pengolahan hasil meliputi teknologi pasca panen dan pengemasan hasil pertanian. Informasi pemasaran juga dibutuhkan oleh petani terutama berkaitan dengan informasi harga produk pertanian. Informasi iklim yang dibutuhkan oleh petani terutama kondisi agroklimatologi dan ramalan cuaca karena hal tersebut berkaitan dengan waktu penanaman. Informasi lain yang dibutuhkan oleh petani yaitu berkaitan dengan permodalan meliputi akses untuk memperoleh kredit usaha tani. Berdasarkan Tabel 8 terlihat bahwa semua jenis informasi dibutuhkan oleh penyuluh. Hal tersebut karena semua informasi tersebut mendukung kinerja penyuluh dan sesuai dengan kebutuhan petani. Andriaty and Setyorini (2012) dalam penelitiannya bahwa masalah yang dihadapi petani dalam berusahatani bervariasi antarlokasi 
sehingga teknologi yang diperlukan pun berbeda, namun umumnya berkaitan dengan teknologi produksi. Berangkat dari permasalahan tersebut, penyuluh berusaha untuk memenuhi kebutuhan informasi petani tersebut melalui berbagai pencarian di media sosial yang dapat dijangkau.

\section{Motivasi Penyuluh Memanfaatkan Media Sosial}

Motivasi memanfaatkan media sosial adalah alasan yang mendorong penyuluh pertanian untuk memanfaatkan media sosial sebagai sumber informasi pertanian. Salah satu motivasi penyuluh dalam memanfaatkan media sosial adalah untuk meningkatkan pengetahuan dan wawasan dalam bidang pertanian. Motivasi lain penyuluh dalam memanfaatkan media sosial adalah untuk mendapatkan informasi baru terutama inovasi dan teknologi baru bidang petanian. Keinginan untuk memecahkan permasalahan yang dihadapi petani juga merupakan salah satu motivasi penyuluh dalam memanfaatkan media sosial. Motivasi lain penyuluh dalam memanfaatkan media sosial adalah untuk meningkatkan profesionalisme dalam kapasitasnya sebagai penyuluh. Tabel 9 merupakan gambaran distribusi penyuluh berdasarkan motivasinya dalam memanfaatkan media sosial.

Tabel 9. Persentase penyuluh berdasarkan motivasi memanfaatkan media sosial

\begin{tabular}{lccccccc}
\hline \multirow{2}{*}{ Motivasi menggunakan media sosial } & \multicolumn{5}{c}{ Jumlah dan persentase penyuluh } \\
\cline { 2 - 7 } & \multicolumn{2}{c}{ Rendah } & \multicolumn{3}{c}{ Sedang } & \multicolumn{2}{c}{ Tinggi } \\
\cline { 2 - 7 } & (orang) & $(\%)$ & (orang) & $(\%)$ & (orang) & $(\%)$ \\
\hline Meningkatkan pengetahuan dan & 5 & 4.00 & 60 & 48.00 & 60 & 48.00 \\
wawasan & 5 & 4.00 & 62 & 49.60 & 58 & 46.40 \\
Mendapatkan informasi baru & 3 & 2.40 & 56 & $4 ., 8$ & 66 & 52.80 \\
Memecahkan permasalahan di lapangan & 8 & 6.40 & 58 & 46.40 & 59 & 47.20 \\
Meningkatkan profesionalisme & &
\end{tabular}

Berdasarkan Tabel 9 bahwa motivasi tertinggi penyuluh memanfaatkan media sosial adalah karena keinginan untuk memecahkan permasalahan di lapangan (52.80\%). Hal tersebut karena penyuluh mempunyai motivasi yang tinggi dalam mencari solusi terhadap permasalahan yang dihadapi oleh petani di wilayah binaannya. Hal tersebut yang mendorong penyuluh harus intensif dalam mengakses media sosial sebelum mengadakan pertemuan di kelompok tani karena selain sebagai ajang silaturahmi, pertemuan tersebut juga berfungsi sebagai wahana diskusi antara petani dan penyuluh pertanian. Menurut Herzberg (2000) dalam Bahua (2018) bahwa kondisi pekerjaan seseorang dipengaruhi salah satunya oleh faktor yang sifatnya intrinsik atau bersumber dalam diri seseorang.

\section{Hubungan Pemanfaatan Media Sosial dengan karakteristik Penyuluh Pertanian}

Hubungan pemanfaatan media sosial dengan karakteristik penyuluh dapat dilihat dari besaran nilai koefisien korelasi (Tabel 10).

Tabel 10. Nilai koefisien korelasi Rank Spearman berdasarkan hubungan pemanfaatan media sosial dengan karakteristik penyuluh

\begin{tabular}{lrrrrrrrr}
\hline & \multicolumn{7}{c}{ Nilai Koefisien korelasi } \\
\cline { 2 - 9 } Karakteristik Individu & \multicolumn{7}{c}{ Frekuensi } & \multicolumn{7}{c}{ Durasi } \\
\cline { 2 - 9 } & \multicolumn{1}{c}{ Fb } & \multicolumn{1}{c}{ Yb } & \multicolumn{1}{c}{ Ig } & \multicolumn{1}{c}{ Fb } & Yb & \multicolumn{1}{c}{ Wa } & \multicolumn{1}{c}{ Ig } \\
\hline Umur & -0.086 & -0.120 & -0.068 & 0.034 & -0.054 & 0.102 & 0.015 & 0.008 \\
Tingkat pendidikan & 0.025 & 0.084 & 0.017 & -0.157 & 0.112 & 0.082 & $0.205^{*}$ & -0.019 \\
Tingkat penghasilan & -0.024 & 0.070 & -0.133 & 0.210 & 0.093 & 0.044 & 0.112 & -0.053 \\
Kepemilikan alat & 0.008 & 0.007 & -0.066 & 0.118 & $0.209^{*}$ & 0.043 & $0.185^{*}$ & 0.280 \\
teknologi informasi & & & & & & & &
\end{tabular}

Keterangan: *Berhubungan nyata pada $\alpha=0.05$

$\mathrm{Fb}=$ Facebook, $\mathrm{YB}=$ Youtube, Wa $=$ WhatsApp, Ig= Instagram

Tabel 10 menunjukkan karakteristik penyuluh tidak berhubungan dengan frekuensi pemanfaatan pada semua media sosial. Selain itu karakteristik penyuluh tidak berhubungan dengan durasi pemanfaatan medsos Youtube dan Instagram $(\mathrm{P}<0.05)$. Indikator umur dan tingkat pendapatan tidak berhubungan dengan frekuensi maupun durasi pemanfaatan media sosial. Indikator tingkat pendidikan hanya 
memiliki hubungan positif dan nyata dengan durasi pemanfaatan media sosial WhatsApp. Hal tersebut menunjukkan semakin tinggi pendidikan, maka durasi dalam mengakses media sosial WhatsApp juga semakin tinggi. Pendidikan merupakan salah satu proses pengembangan pengetahuan, ketrampilan maupun sikap penyuluh agar mampu berpartisipasi aktif dalam kegiatan. Hal tersebut sejalan dengan penelitian Sartika (2018) bahwa kegunaan WhatsApp sebagai media informasi sangat berperan dalam memberikan serta menyebarkan informasi ke orang lain. Pada indikator kepemilikan alat teknologi informasi hanya memiliki hubungan positif dan nyata dengan durasi penyuluh dalam mengakses informasi lewat Facebook dan WhatsApp. Hal tersebut menunjukkan bahwa semakin banyak kepemilikan alat teknologi komunikasi maka akan semakin tinggi durasi pemanfaatan media sosial terutama Facebook dan WhatsApp oleh penyuluh. Christian \& Subejo (2018) menyatakan bahwa kepemilikan alat teknologi informasi berbanding lurus dengan intensitas pemanfaatan yang sering salah satunya dalam pencarian informasi.

Menurut Elian (2014) salah satu faktor yang berhubungan dengan pemanfaatan internet adalah ketersediaan alat teknologi, dalam hal ini termasuk kepemilikan alat teknologi. Hal tersebut juga berlaku pada pemanfaatan media sosial dalam penelitian ini. Pernyataan tersebut juga didukung oleh penelitian Anwas et al. (2009) yang menyatakan bahwa intensitas pemanfaatan media yang rendah disebabkan oleh jumlah kepemilikan media meskipun tingkat pendidikan formalnya tinggi. Dalam hal ini secara masing-masing baik pendidikan maupun kepemilikan alat teknologi informasi (handphone, smartphone, laptop, netbook, komputer dan lainnya) mempunyai hubungan terhadap pemanfaatan media sosial oleh penyuluh pertanian.

\section{Hubungan Pemanfaatan Media Sosial dengan Kebutuhan Informasi Penyuluh}

Faktor lainnya yang berhubungan dengan pemanfaatan media sosial oleh penyuluh adalah kebutuhan informasi. Pada Tabel 11 diketahui kebutuhan informasi tentang iklim mempunyai hubungan yang positif dan nyata dengan frekuensi maupun durasi pemanfaatan media sosial Facebook, Youtube dan WhatsApp. Hal tersebut menunjukkan bahwa informasi mengenai iklim adalah salah satu informasi yang cukup sering diakses oleh penyuluh pertanian melalui media sosial yang dimaksud. Sedangkan kebutuhan informasi tentang permodalan mempunyai hubungan yang positif dan nyata dengan durasi pemanfaatan media sosial Facebook saja. Hubungan yang ada relatif kecil sehingga hal tersebut tidak sesuai dengan kondisi di lapangan. Hasil wawancara menunjukkan bahwa sebagian besar penyuluh membutuhkan informasi tentang teknologi produksi. Penyuluh mendapatkan informasi teknologi produksi tersebut tidak hanya dari media sosial tetapi dari media lainnya. Menurut Vintarno et al. (2019) penyuluh harus mampu mengakses informasi pasar, teknologi, permodalan dan sumberdaya lainnya sebagai upaya meningkatkan kesadaran dalam pelestarian fungsi lingkungan hidup. Pernyataan tersebut juga didukung Dewi (2011) bahwa informasi mengenai modal sangat membantu petani untuk mengembangkan usaha taninya.

Tabel 11. Nilai koefisien korelasi Rank Spearman berdasarkan hubungan pemanfaatan media sosial dengan kebutuhan informasi responden

\begin{tabular}{|c|c|c|c|c|c|c|c|c|}
\hline \multirow{3}{*}{ Kebutuhan informasi } & \multicolumn{8}{|c|}{ Nilai Koefisien korelasi } \\
\hline & \multicolumn{4}{|c|}{ Frekuensi } & \multicolumn{4}{|c|}{ Durasi } \\
\hline & $\mathbf{F b}$ & $\mathbf{Y b}$ & Wa & Ig & $\mathbf{F b}$ & $\mathbf{Y b}$ & Wa & Ig \\
\hline Teknologi produksi & 0.007 & -0.021 & -0.054 & 0.025 & 0.029 & -0.066 & 0.017 & -0.215 \\
\hline $\begin{array}{l}\text { Teknologi pengolahan } \\
\text { hasil }\end{array}$ & 0.010 & 0.087 & 0.028 & 0.241 & 0.132 & 0.023 & 0.093 & -0.004 \\
\hline Pemasaran & 0.045 & 0.061 & 0.020 & 0.013 & 0.163 & 0.046 & 0.153 & -0.127 \\
\hline Iklim & $0.193 *$ & $0.190 *$ & 0.137 & 0.216 & $0.216^{*}$ & 0.069 & $0.213^{*}$ & 0.124 \\
\hline Permodalan & 0.064 & 0.105 & 0.084 & 0.103 & $0.209 *$ & 0.064 & 0.176 & -0.018 \\
\hline
\end{tabular}

$\mathrm{Fb}=$ Facebook, $\mathrm{YB}=$ Youtube, $\mathrm{Wa}=$ WhatsApp, Ig= Instagram

\section{Hubungan Pemanfaatan Media Sosial dengan Motivasi Penyuluh}

Motivasi penyuluh memanfaatkan media sosial mempunyai hubungan yang nyata dan hanya relatif kecil pada pemanfaatan media sosial Facebook. Hubungan tersebut pada motivasi untuk meningkatkan pengetahuan dan wawasannya. Menurut Sasmito (2015) bahwa media sosial Facebook adalah salah 
satu media sosial yang memiliki fitur-fitur aplikasi yang digunakan untuk berkomunikasi dengan pengguna lainnya mulai dari pendidikan, bisnis dan entertainment. Fungsi dari Facebook sendiri adalah untuk penyampaian materi, sarana pembelajaran dan sebagai wahana diskusi.

Berdasarkan hasil wawancara untuk mendapatkan informasi baru, memecahkan permasalahan di lapangan serta meningkatkan profesionalisme, penyuluh lebih banyak menggunakan sumber informasi lain seperti pertemuan rutin, diskusi bulanan, seminar, pelatihan, publikasi (leaflet, brosur, dan lainlain). Hal tersebut disebabkan akses terhadap sumber informasi tersebut lebih mudah, cukup tersedia dalam jumlah yang relatif banyak dan informasi yang diperoleh juga sesuai dengan yang dibutuhkan oleh penyuluh pertanian.

Tabel 12. Nilai koefien korelasi Rank Spearman berdasarkan hubungan pemanfaatan media sosial dengan motivasi responden

\begin{tabular}{|c|c|c|c|c|c|c|c|c|}
\hline \multirow{3}{*}{$\begin{array}{c}\text { Motivasi memanfaatkan } \\
\text { media sosial }\end{array}$} & \multicolumn{8}{|c|}{ Nilai Koefisien korelasi } \\
\hline & \multicolumn{4}{|c|}{ Frekuensi } & \multicolumn{4}{|c|}{ Durasi } \\
\hline & Fb & Yb & Wa & Ig & $\mathbf{F b}$ & Yb & Wa & Ig \\
\hline $\begin{array}{l}\text { Meningkatkan } \\
\text { pengetahuan dan } \\
\text { wawasan }\end{array}$ & $0,219^{*}$ & 0,156 & 0,025 & 0,075 & $0,187 *$ & 0,173 & 0,166 & 0,112 \\
\hline $\begin{array}{l}\text { Mendapatkan informasi } \\
\text { baru }\end{array}$ & 0,124 & 0,070 & 0,076 & 0,054 & 0,111 & 0,082 & 0,173 & 0,098 \\
\hline $\begin{array}{l}\text { Memecahkan } \\
\text { permasalahan di lapangan }\end{array}$ & 0,082 & $-0,077$ & $-0,057$ & $-0,169$ & 0,124 & 0,024 & 0,123 & $-0,019$ \\
\hline $\begin{array}{l}\text { Meningkatkan } \\
\text { profesionalisme }\end{array}$ & 0,121 & $-0,065$ & $-0,010$ & 0,113 & 0,089 & $-0,007$ & 0,069 & 0,032 \\
\hline
\end{tabular}

\section{Pengelolaan Informasi Pertanian oleh Penyuluh Pertanian}

Penyuluh pertanian sesuai dengan tugas pokok dan fungsinya berkedudukan sebagai pelaksana teknis fungsional yang mempunyai tugas menyiapkan, melaksanakan, mengembangkan, mengevaluasi dan melaporkan kegiatan penyuluhan pertanian. Untuk itu penyuluh pertanian memerlukan dukungan informasi yang cukup dalam menjalankan tugasnya. Informasi pertanian yang diperoleh dapat dimanfaatkan untuk meningkatkan kinerja, prestasi kerja dan kompetensi penyuluh pertanian.

Pengelolaan informasi pertanian adalah perilaku penyuluh dalam mengelola informasi pertanian yang diperolehnya melalui media sosial. Informasi yang diperoleh dari media sosial tersebut dapat digunakan sebagai bahan penyusunan rancangan program penyuluhan, bahan penyusunan rencana kerja penyuluh pertanian, bahan materi penyuluhan dan lain sebagainya. Pengelolaan informasi pertanian pada penelitian ini diukur berdasarkan pemanfaatannya, apakah disimpan untuk pribadi, dibagikan ke sesama penyuluh atau disebarkan ke petani (Gambar 1).

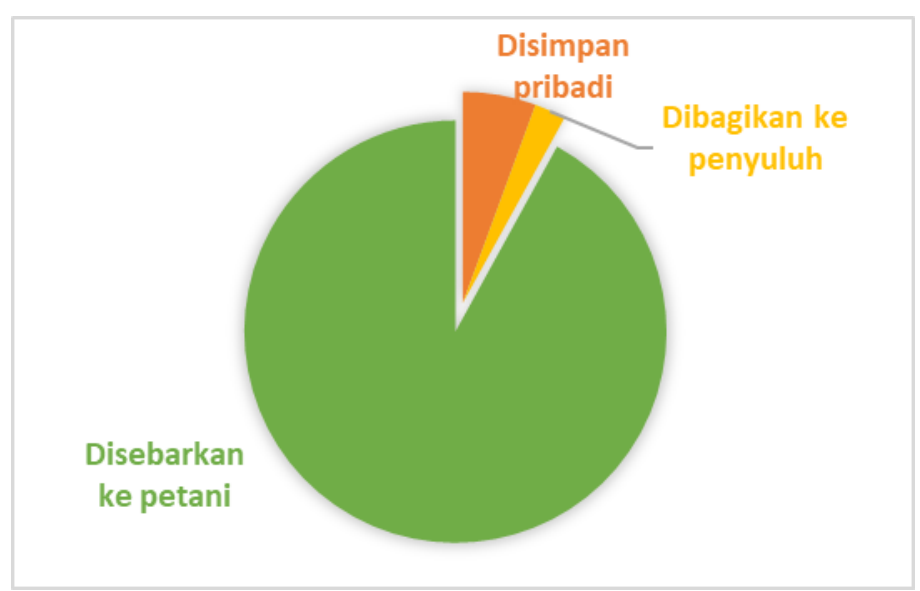

Gambar 1. Persentase penyuluh berdasarkan pengelolaan informasi pertanian 
Berdasarkan Gambar 1 di atas terlihat bahwa sebagian besar penyuluh pertanian (92\%) yang ada di kabupaten Minahasa mengelola informasi pertanian yang diperoleh dari media sosial untuk disebarkan kepada petani, hanya sebagian kecil yang disimpan untuk referensi pribadi maupun untuk dibagikan ke sesama penyuluh sebagai bahan diskusi. Sebagian besar penyuluh mencari informasi pertanian di media sosial dalam rangka melengkapi informasi yang sudah ada, informasi yang sudah ada dan belum lengkap biasanya menjadi bahan diskusi ke sesama penyuluh. Kondisi tersebut sudah sesuai dengan tugas pokok penyuluh sebagai media penghubung dari sumber informasi kepada petani. Ketika informasi sudah lengkap baru disebarkan kepada petani. Hal ini sesuai dengan pernyataan Padmanegara (1980) dalam Syahyuti (2014) bahwa tugas seorang penyuluh antara lain menyebarkan informasi pertanian yang bermanfaat, mengajarkan ketrampilan dan kecakapan bertani yang lebih baik, memberikan rekomendasi berusaha tani yang lebih menguntungkan, mengikhtiarkan fasilitas produksi dan usaha yang lebih menguntungkan dan menggairahkan serta menumbuhkan swadaya dan swadana dalam usaha perbaikan dalam usahatani.

Selanjutnya. Tamba and Sarma (2007) menjelaskan bahwa faktor yang menentukan tingkat kebutuhan informasi pertanian antara lain: status sosial ekonomi, tingkat kesadaran akan pentingnya informasi, kemampuan untuk akses ke sumber informasi pertanian, tingkat motivasi dan tingkat keinovatifan. Adanya perbedaan tingkat kebutuhan petani terhadap berbagai jenis informasi pertanian akan mempengaruhi upaya penyediaan informasi yang dibutuhkan oleh petani. Dengan demikian, penyuluh pertanian dituntut untuk selalu memperbaharui atau mengkaji ulang kebutuhan informasi dari petani sebagai komunitas binaanya secara periodik, karena seiring dengan berjalannya waktu dan perubahan lingkungan sosial maka kebutuhan petani dapat saja berubah.

\section{KESIMPULAN}

Dari hasil penelitian tentang pemanfaatan media sosial untuk mendukung kegiatan penyuluh pertanian ini dapat disimpukan bahwa pemanfaatan media sosial oleh penyuluh pertanian tergolong pada kategori tinggi yaitu pada pemanfaatan media sosial Facebook dan WhatsApp, pemanfaatan media sosial Youtube dan Instagram tergolong pada kategori sedang. Hampir seluruh penyuluh pertanian mengakses media sosial baik Facebook, Youtube, WhatsApp maupun Instagram kurang dari tiga jam sehari (rendah). Faktor-faktor yang memiliki hubungan dengan pemanfaatan media sosial adalah (1) karakteristik penyuluh berupa tingkat pendidikan dan kepemilikan alat teknologi informasi; (2) persepsi penyuluh terhadap kemudahan mengakses informasi melalui media sosial; (3) kebutuhan informasi penyuluh yaitu iklim dan permodalan dan (4) motivasi penyuluh dalam meningkatkan pengetahuan dan wawasan. Pengelolaan informasi pertanian oleh penyuluh pertanian sudah pada tahap yang seharusnya, dimana hampir seluruh penyuluh pertanian menyebarkan informasi yang diperoleh dari media sosial kepada petani, hanya beberapa penyuluh saja yang memanfaatkan informasi tersebut untuk disimpan sebagai referensi pribadi maupun dibagikan kepada sesama penyuluh pertanian.

\section{DAFTAR PUSTAKA}

Amanah, S. (2008). Sistem Penyuluhan Perikanan Dalam Mengantisipasi Era Perubahan. Jurnal Penyuluhan, 4(2), 139-151. https://doi.org/10.25015/penyuluhan.v4i2.2180

Amin, M., Sugiyanto, Sukesi, K., \& Ismadi. (2013). Application of Cyber Extension as Communication Media to Empower the Dry Land Farmer at Donggala District, Central Sulawesi. J. Basic. Appl. Sci. Res, 3(4), 379-385. https://www.textroad.com/pdf/JBASR/J. Basic. Appl. Sci. Res., 3(4)379-385, 2013.pdf

Andriaty, E., \& Setyorini, E. (2012). Ketersediaan Sumber Informasi Teknologi Pertanian Di Beberapa Kabupaten Di Jawa. Jurnal Perpustakaan Pertanian, 21(1), 30-35. https://doi.org/10.21082/jpp.v21n1.2012.p

Anwas, E. O. M., Sumardjo, Asngari, P. S., \& Tjitropranoto, P. (2009). Faktor-Faktor yang Mempengaruhi Penyuluh dalam Pemanfaatan Media. Jurnal Komunikasi Pembangunan, 7(2), 68-81.

Anwas, E. Oos Mukhamad. (2009). Pemanfaatan Media dalam Pengembangan Kompetensi Penyuluh Pertanian (Kasus di Kabupaten Karawang dan Garut Provinsi Jawa Barat) [Institut Pertanian Bogor]. https://doi.org/10.25015/penyuluhan.v6i1.10660 
Bahua, M. I. (2018). Peran Motivasi Dan Kinerja Penyuluh Pertanian Dalam Mengubah Perilaku Petani Jagung. Jurnal Sosial Ekonomi Pertanian, 14(3), 225-232. https://doi.org/10.20956/jsep.v14i3.5275

Bahua, M. I., Jahi, A., Asngari, P. S., Saleh, A., \& Purnaba, G. P. (2010). Faktor-Faktor yang Mempengaruhi Kinerja Penyuluh Pertanian dan Dampaknya pada Perilaku Petani Jagung Di Provinsi Gorontalo. Jurnal Ilmiah Agropolitan, 3(1), 293-303.

Christian, A. I., \& Subejo, S. (2018). Akses, Fungsi, Dan Pola Penggunaan Teknologi Informasi Dan Komunikasi (Tik) Oleh Petani Pada Kawasan Pertanian Komersial Di Kabupaten Bantul. JSEP (Journal of Social and Agricultural Economics), 11(2), 25-30. https://doi.org/10.19184/jsep.v11i2.9233

Dasli, A. P. E., Muljono, P., \& Susanto, D. (2015). Pemanfaatan Cyber Extension melalui Telepon Genggam oleh Petani Anggrek di Taman Anggrek Ragunan, Jakarta Selatan. Jurnal Penyuluhan, 11(2), 103-115.

Destrian, O., Wahyudin, U., \& Mulyana, S. (2018). Perilaku Pencarian Informasi Pertanian melalui Media Online pada Kelompok Petani Jahe. Jurnal Kajian Komunikasi, 6(1), 121-132.

Dewi, I. A. L. (2011). Akses Informasi Pasar, Modal, dan Teknologi oleh Petani di Daerah Perkotaan. DwijenAGRO, 2(2), 1-13.

Elian, N. (2014). Penggunaan Internet Dan Pemanfaatan Informasi Pertanian Oleh Penyuluh Pertanian Di Wilayah Barat Kabupaten Bogor. Institut Pertanian Bogor.

Elian, N., Lubis, D. P., \& Rangkuti, P. A. (2014). Penggunaan Internet dan Pemanfaatan Informasi Pertanian oleh Penyuluh Pertanian di Kabupaten Bogor Wilayah Barat. Jurnal Komunikasi Pembangunan, 12(2), 104-109. https://doi.org/10.29244/jurnalkmp.12.2.\%p

Faiqah, F., Nadjib, M., \& Amir, A. S. (2016). Youtube sebagai Sarana Komunikasi bagi Komunitas Makassarvidgram. Jurnal Komunikasi KAREBA, 5(2), 259-272. https://doi.org/10.1080/14639947.2015.1006801

Helen, \& Rusdi, F. (2018). Pengaruh Penggunaan Media Sosial Akun Instagram @ Jktinfo Terhadap Pemenuhan Kebutuhan Informasi Followers. Prologia, 2(2), 355-362. https://doi.org/10.24912/pr.v2i2.3712

Humaidi, L., Hubeis, A. V. S., Puspitawati, H., \& Anwas, E. O. M. (2020). Pengaruh Dukungan Lembaga dan Pemanfaatan Media Sosial terhadap Kompetensi Penyuluh Pertanian di Provinsi Kepulauan Riau. Jurnal Pengkajian Dan Pengembangan Teknologi Pertanian, 23(1), 25-49.

Kushartanti, E. (2001). Keefektifan Media Cetak pada Diseminasi dan Adopsi Teknologi Jagung Bisma di Kabupaten Semarang. Universitas Gadjah Mada.

Margono, T., \& Sugimoto, S. (2011). The Barriers of the Indonesian Extension Workers in Disseminate Agricultural Information to Farmers. International Journal of Basic \& Applied Sciences IJBAS-IJENS, 11(2), 80-86. http://www.ijens.org/Vol 11 I 02/117302-4747 IJBASIJENS.pdf

Marius, J. A., Sumardjo, Slamet, M., \& S. Asngari, P. (2007). Pengaruh Faktor Internal dan Eksternal Penyuluh terhadap Kompetensi Penyuluh di Nusa Tenggara Timur. Jurnal Penyuluhan, 3(2), 78-89.

Marliati, M., Sumardjo, S., Asngari, P. S., Tjitropranoto, P., \& Saefuddin, A. (2008). Faktor-faktor Penentu Peningkatan Kinerja Penyuluh Pertanian dalam Memberdayakan Petani (Kasus di Kabupaten Kampar Provinsi Riau). Jurnal Penyuluhan, 4(2), 92-99. https://doi.org/10.25015/penyuluhan.v4i2.2174

Matthew, A. O., Paschalene, E. O., \& Amechi, O. E. (2017). Challenges of Extension Workers in Reaching Rural Women Farmers in Enugu State Nigeria. Journal of Agricultural Extension, 21(3), 22-36.

Mulyandari, R. S. H. (2011). Cyber Extension Sebagai Media Komunikasi dalam Pemberdayaan Petani Sayuran. Institut Pertanian Bogor.

Nurfathiyah, P. (2019). Faktor-Faktor Yang Mempengaruhi Penyuluh Pertanian Dalam Pemanfaatan Media Informasi Di Kabupaten Batanghari. Jurnal Ilmiah Ilmu Terapan Universitas Jambi, $3(1), 78-92$.

Pertiwi, W. K. (2019). Hampir Setengah Penduduk Bumi sudah "Melek” Media Sosial. Kompas.Com. 
https://tekno.kompas.com/read/2019/07/20/16370017/hampir-setengah-penduduk-bumi-sudahmelek-media-sosial

Rachmaniar, \& Anisa, R. (2017). Studi Deskriptif Tentang Loyalitas Peserta Grup Whatsapp. Sosioglobal: Jurnal Pemikiran Dan Penelitian Sosiologi, 2(1), 32-39. https://doi.org/10.24198/jsg.v2i1.15269

Riyanto, A. D. (2019). Hootsuite (We are Social): Indonesian Digital Report 2019. Andi.Link. https://andi.link/hootsuite-we-are-social-indonesian-digital-report-2019/

Ruggiero, T. E. (2000). Mass communication and society uses and gratifications theory in the $21 \mathrm{st}$ Century. Mass Communication and Society, 3(1), 3-37. https://doi.org/10.1207/S15327825MCS0301

Sartika. (2018). Kegunaan Whatsapp Sebagai Media Informasi Dan Media Pembelajaran pada Mahasiswa Ilmu Komunikasi STISIP Persada Bunda. Medium, 6(2), 15-26.

Sasmito, M. (2015). Pemanfaatan Media Sosial Facebook untuk Media Pembelajaran Bahasa Indonesia. Jurnal Online Universitas Muhammadiyah Purwokerto, 1(2), 184-198.

Suhanda, N. S., Jahi, A., Sugihen, B. G., \& Susanto, D. (2008). Kinerja Penyuluh Pertanian Di Jawa Barat. Jurnal Penyuluhan, 4(2), 100-108.

Suharjon, Marwanti, S., \& Irianto, H. (2017). Pengaruh Ekspor, Impor, dan Investasi terhadap Pertumbuhan Sektor Pertanian Indonesia. Jurnal Agro Ekonomi, 35(1), 49-65. https://doi.org/10.21082/jae.v35n1.2017.49-65

Supratman, L. P. (2018). Penggunaan Media Sosial oleh Digital Native. Jurnal ILMU KOMUNIKASI, 15(1), 47-60. https://doi.org/10.24002/jik.v15i1.1243

Syahyuti. (2014). Peran Strategis Penyuluh Swadaya dalam Paradigma Baru Penyuluhan Pertanian Indonesia. Forum Penelitian Agro Ekonomi, 32(1), 43-58. https://doi.org/10.21082/fae.v32n1.2014.43-58

Tamba, M., \& Sarma, M. (2007). Faktor-Faktor Yang Mempengaruhi Kebutuhan Informasi Pertanian Bagi Petani Sayuran Di Provinsi Jawa Barat. Jurnal Penyuluhan, 3(1), 24-34. https://doi.org/10.25015/penyuluhan.v3i1.2148

Viforit, A., Hasyim, H., \& Khadijah, S. (2014). Pengaruh Karakteristik Sosial Ekonomi Penyuluh terhadap Tingkat Keberhasilan Pelaksanaan Tugas Pokok Penyuluh Pertanian (di BPP Pematang Sijonam, Kabupaten Serdang Bedagai). Jurnal Sosial Ekonomi Pertanian Dan Agribisnis, 3(5), $1-16$.

Vintarno, J., Sugandi, Y. S., \& Adiwisastra, J. (2019). Perkembangan Penyuluhan Pertanian dalam Mendukung Pertumbuhan Pertanian di Indonesia. Responsive, 1(3), 90-96.

Wicaksono, P., Sugiyanto, S., \& Purnomo, M. (2016). Faktor-Faktor yang Berkontribusi Terhadap Kinerja dan Kompetensi Penyuluh Pertanian Pada Jenjang Jabatan Penyuluh Pertanian Ahli (Kasus di Malang, Jawa Timur). Habitat, 27(2), 85-93. https://doi.org/10.21776/ub.habitat.2016.027.2.10 